\title{
GRISEORUBINS, A NEW FAMILY OF ANTIBIOTICS WITH ANTIMICROBIAL AND ANTITUMOR ACTIVITY \\ II. BIOLOGICAL PROPERTIES AND ANTITUMOR ACTIVITY OF THE ANTIBIOTIC COMPLEX GRISEORUBIN
}

\author{
K. Dornberger*, U. Berger, W. Gutsche, W. Jungstand, K. Wohlrabe,
}

\author{
A. HÄrTL and H. KNÖLL†
}

Zentralinstitut für Mikrobiologie und experimentelle Therapie der

Akademie der Wissenschaften der DDR,

DDR-69 Jena, Beutenbergstr. 11, DDR

(Received for publication October 25, 1979)

\begin{abstract}
The antibiotic complex griseorubin has antimicrobial activity against Gram-positive as well as -negative bacteria, mycobacteria, mycoplasma and protozoa in vitro but it is not active against yeast and fungi. Tests with transplantable rodent tumors indicate that griseorubin is inhibitory to the growth of lymphatic leukemia L1210 in mice and ZAJDELA ascites hepatoma in rats. The acute $\mathrm{LD}_{50}$ of griseorubin in mice is $50 \mathrm{mg} / \mathrm{kg}$ of body weight when given intraperitoneally. Attempts to potentiate the antitumor activity by complexing with DNA proved to be unsuccessful.
\end{abstract}

As reported in the preceding paper griseorubin has been characterized as a complex of components belonging to the polycyclic C-glycosyl antibiotics of the "kidamycin" type. The present paper describes the antimicrobial properties of griseorubin and its chemotherapeutic activity against several transplantable rodent tumors.

\section{Material and Methods}

The sample of the griseorubin complex hydrochloride used in this report was prepared according to the procedure described in the preceding paper. Calf thymus DNA was a gift from Mrs. E. SARFERT (Zentralinstitut für Mikrobiologie und experimentelle Therapie Jena). This preparation was described as having an average molecular weight of about 25 millions ${ }^{12}$.

Assay of Antimicrobial Activity

Both the agar diffusion test and the serial dilution test method were used for the determination of MIC in this work.

Anticancer Tests

Griseorubin was tested against leukemia $\mathrm{L} 1210$ on female $\mathrm{NMDF}_{1}(\mathrm{NMRI} \times \mathrm{DBA} 2)$ or $\mathrm{ABD} 2 \mathrm{~F}_{1}$ mice (body weight $18 \sim 24 \mathrm{~g}$ ) and against WALKER 256 carcinosarcoma and ZAJDELA hepatoma on young Wistar rats (body weight about $70 \mathrm{~g}$ at mean time of experiments). Leukemia L1210 was implanted intraperitoneally by $0.2 \mathrm{ml}$ saline containing $5 \times 10^{6}$ leukemic cells per mouse. Treatment was initiated one day after implantation and continued once daily for nine days with a stop of two days following the fourth injection. WALKER 256 carcinosarcoma was propagated subcutaneously by trocar with small fragments of about $3 \sim 4 \mathrm{~mm}$ diameters and treated intraperitoneally once daily for 4 consecutive days. ZAJDELA hepatoma was implanted intraperitoneally by $0.5 \mathrm{ml}$ ascitic fluid. The schedule of treatment was the same as in L1210 system.

* To whom inquiries should be directed.

$\dagger$ Deceased June 26, 1978. 


\section{Griseorubin-DNA Complex}

Calf thymus DNA was dissolved in sterile $0.15 \mathrm{M} \mathrm{NaCl}$ to a concentration of $1.22 \mathrm{mg} / \mathrm{ml}$, autoclaved for 15 minutes at $120^{\circ} \mathrm{C}$, and cooled rapidly. Griseorubin was dissolved in this DNA solution to a final concentration of $0.3 \mathrm{mg} / \mathrm{ml}$. The solution of griseorubin and DNA resulted in an immediate reduction of the polarographic step of griseorubin, indicative of complex formation.

The griseorubin-DNA complex was tested against $\mathrm{L}_{1210}$ on $\mathrm{ABD}_{2} \mathrm{~F}_{1}$ mice as described above. For the study of therapeutic effects, the antibiotic: DNA ratio was 1:4 on the weight basis.

Test for Cytotoxic Effect in Tissue Culture Cells

The cytotoxic effect of griseorubin and the griseorubin-DNA complex was examined against chicken embryo cells grown in monolayers. The samples were dissolved in $0.9 \% \mathrm{NaCl}$ solution in serial twofold dilutions and tested for cytotoxicity on 2-day-old cultures.

Acute Toxicity of Griseorubin

Water dissolved griseorubin was used for acute toxicity in male mice (AB Jena) weighing 18 $23 \mathrm{~g}$. Griseorubin was administered intravenously, intraperitoneally or subcutaneously in increasing doses. The observation period lasted 4 weeks. Approximate $\mathrm{LD}_{50}$ values were estimated according to the mortality of the mice.

\section{Results and Discussion}

\section{Antimicrobial Activities of Griseorubin}

As seen in Table 1 griseorubin exhibited antibacterial activity against a variety of Gram-positive and -negative bacteria. However, no activity was observed against Saccharomyces, Kloeckera, Fusarium, and Penicillium, respectively. The test spectrum differs from that of kidamycin in activity against some Gram-negative bacteria. Unlike kidamycin ${ }^{2)}$ griseorubin was effective against Escherichia coli. Significant activity against mycoplasma was noticed as illustrated in Table 2. Griseorubin had inhibitory activity only against a few species of protozoa. The results of the protozoan test are given in Table 3.

\section{Antitumor Activities of Griseorubin}

The results of in vivo experiments on leukemia L1210, WALKER 256 carcinosarcoma, and ZAJDELA hepatoma are illustrated in Tables $4 \sim 5$. Griseorubin showed a significant increase of survival time in mice bearing L1210 and in rats implanted with ZAJDELA hepatoma. The antibiotic did not exhibit a growth inhibition of WALKER 256 carcinosarcoma. It is further noteworthy that the toxicity of griseorubin is much lower in $\mathrm{ABD}_{2} \mathrm{~F}_{1}$ mice than in $\mathrm{NMDF}_{1}$ mice.

Griseorubin can be distinguished from kidamycin by a stronger antitumor activity against L1210. Kidamycin shows only a slight life-prolongation of about $10 \%$ at total doses of $18,13.5$, and $9 \mathrm{mg} / \mathrm{kg}$ when it was administered daily intraperitoneally for 8 days $^{33}$.

In attempts to enhance the antitumor activity of griseorubin without concomitant increase of host toxicity a griseorubin-DNA complex was prepared and administered to mice bearing L1210. Complexes formed with DNA as carrier behave like lysosomotropic drugs ${ }^{4)}$. They are endocytized and the drugs are released intracellularly in a free form after intralysosomal digestion of the carrier. Under in vivo conditions a potentiation of the antitumor activity of adriamycin, daunomycin, and actinomycin D has been described ${ }^{5 \sim 9}$.

Griseorubin forms a complex with DNA in vitro. The amount of calf thymus DNA required to bind griseorubin completely was determined by observing the change in the polarographic step of griseorubin as increasing amounts of DNA were added. Specially the anthracyclines exhibit pro- 
Table 1. In vitro antimicrobial activity of griseorubin as determined by the agar diffusion test method.

\begin{tabular}{|c|c|}
\hline Test organisms & $\begin{array}{c}\mathrm{MIC} \\
(\mathrm{mcg} / \mathrm{ml})\end{array}$ \\
\hline Bacillus subtilis ATCC 6633 & 15 \\
\hline Escherichia coli $\mathrm{C} 600$ & 15 \\
\hline Escherichia coli SG 458 & 15 \\
\hline Serratia marcescens SG 621 & 62 \\
\hline Aerobacter aerogenes SG 117 & 15 \\
\hline Pseudomonas sp. B 7 & 31 \\
\hline Pseudomonas aeruginosa SG 137 & 125 \\
\hline Bacillus globifer $\mathrm{OH} 11$ & 15 \\
\hline Bacillus globifer EH 11 & 31 \\
\hline Mycobacterium phlei SG 346 & 15 \\
\hline Mycobacterium smegmatis SG 987 & 15 \\
\hline Corynebacterium equi SG 1144 & 15 \\
\hline $\begin{array}{l}\text { Corynebacterium mediolanum } \\
\text { SG } 1145\end{array}$ & 15 \\
\hline $\begin{array}{l}\text { Corynebacterium diphtheriae } \\
\text { Typ gravis }\end{array}$ & 31 \\
\hline $\begin{array}{l}\text { Corynebacterium diphtheriae } \\
\text { Typ mitis }\end{array}$ & 31 \\
\hline $\begin{array}{l}\text { Corynebacterium diphtheriae } \\
\text { Typ intermed. }\end{array}$ & 15 \\
\hline
\end{tabular}

Table 4. Effectiveness of griseorubin on leukemia L1210.

\begin{tabular}{c|c|c}
\hline \multirow{2}{*}{$\begin{array}{c}\text { Doses } \\
\text { (mg/kg mouse) }\end{array}$} & \multicolumn{2}{|c}{ MIT } \\
\cline { 2 - 3 } 30 & $\mathrm{NMDF}_{1}$ mice & $\mathrm{ABD}_{2} \mathrm{~F}_{1}$ mice \\
15 & tox** & $34.5^{* *}$ \\
7.5 & tox**** & $16.1^{* *}$ \\
4 & $2.2^{* * *}$ & $19.4^{* *}$ \\
2 & $18.5^{* * *}$ & 16.1 \\
1 & $51.9^{* * *}$ & 8.7 \\
0.5 & 38.4 & 10.5 \\
\hline
\end{tabular}

*** mean values of 3 experiments

**: mean values of 2 experiments remainder 1 experiment

MIT: mean increase of survival time in $\%$ of untreated controls

Day of L1210 injection is first day of experiment.
Table 2. In vitro susceptibility of Mycoplasma species to griseorubin as determined by the serial dilution test method.

\begin{tabular}{|c|c|c|}
\hline \multirow{2}{*}{ Test organisms } & \multicolumn{2}{|c|}{$\mathrm{MIC}(\mathrm{mcg} / \mathrm{ml})$} \\
\hline & $\begin{array}{l}\text { Bacterio- } \\
\text { static }\end{array}$ & $\begin{array}{c}\text { Bacterio- } \\
\text { cidal }\end{array}$ \\
\hline Mycoplasma gallisepticum S 6 & 0.16 & 4 \\
\hline Mycoplasma hyorhinis & 0.16 & 4 \\
\hline
\end{tabular}

Table 3. In vitro susceptibility of protozoa species to griseorubin as determined by the serial dilution test method.

\begin{tabular}{l|c|c}
\hline \multicolumn{1}{c|}{ Test organisms } & \multicolumn{2}{|c}{ MIC $(\mathrm{mcg} / \mathrm{ml})$} \\
\hline $\begin{array}{c}\text { Protozoa- } \\
\text { static }\end{array}$ & $\begin{array}{c}\text { Protozoa- } \\
\text { cidal }\end{array}$ \\
\hline Trypanosoma equiperdum K 48 & 0.1 & 10 \\
Trypanosoma gambiense K 51 & 0.25 & 10 \\
\hline
\end{tabular}

Table 5. Effectiveness of griseorubin on WALKER 256 carcinosarcoma and ZAJDELA hepatoma.

\begin{tabular}{c|c|c}
\hline $\begin{array}{c}\text { Doses } \\
\text { (mg/kg rat) }\end{array}$ & $\begin{array}{c}\text { WALKER 256 } \\
\text { MIG }\end{array}$ & $\begin{array}{c}\text { ZAJDELA } \\
\text { hepatoma } \\
\text { MIT }\end{array}$ \\
\hline 8.6 & tox $^{*}$ & 33.3 \\
4.3 & $20.1^{*}$ & 32.2 \\
2.15 & $15.7^{*}$ & 35.2 \\
1.1 & $11.1^{*}$ & 21.6 \\
0.6 & $6.2^{*}$ & 19.9 \\
0.3 & 4.3 & 24.4 \\
\hline
\end{tabular}

* Mean values of 2 experiments remainder 1 experiment

MIG: mean inhibition of tumor growth in $\%$ of untreated controls

MIT: mean increase of survival time in $\%$ of untreated controls

Day of tumor injection is first day of experiment.

nounced signals by all polarographic techniques suitable for analytical measurements and binding studies $^{10)}$, see Fig. 1.

However, under conditions used it was found that the griseorubin-DNA complex was not more effective than the free griseorubin in prolonging survival of $A B D 2 F_{1}$ mice bearing L1210.

On the other hand, the griseorubin-DNA complex exhibited a reduced cytotoxic effect on the 
growth of cultured chicken embryo cells in vitro in comparison with the free griseorubin. The maximum tolerate dose of griseorubin was 6.25 $\mathrm{mcg} / \mathrm{ml}$ unlike the griseorubin-DNA complex which displayed a maximum tolerate level of $>100 \mathrm{mcg} / \mathrm{ml}$ referring to griseorubin.

The $\mathbf{L D}_{50}$ values of griseorubin in mice were determined to be $10 \mathrm{mg} / \mathrm{kg}$ of body weight by intravenous, $50 \mathrm{mg} / \mathrm{kg}$ by intraperitoneal, and $100 \mathrm{mg} / \mathrm{kg}$ by subcutaneous injection, respectively. When the intoxication was lethal the animals died during the sixth and twelfth day after administration independent of the application route. The intraperitoneal injection of griseorubin led to a serious chronic fibroblastic peritonitis, the subcutaneous injection to skin necrosis.
Fig. 1. Titration curve of griseorubin $\left(6 \times 10^{-3} \mathrm{mg} / \mathrm{ml}\right.$ in $0.9 \% \mathrm{NaCl}$ solution $)$

$\mathrm{hr}$ : Relative polarographic step height of griseorubin

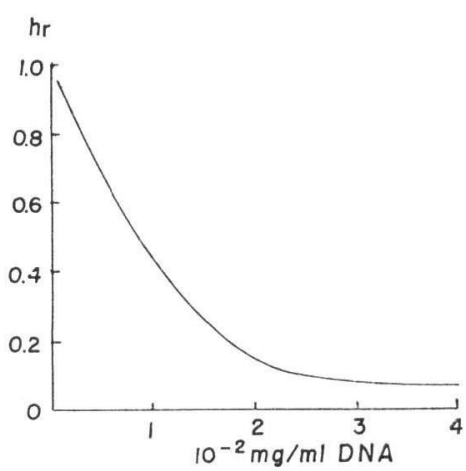

\section{Acknowledgements}

We wish to express our appreciation to various members of our Institute who contributed to this work. In particular, we wish to thank Prof. Dr. H. Berg for the polarographic studies, Dr. CH. Schönfeld for the test against protozoa, and Dr. E. Tonew for the tissue cell culture cytotoxicity test.

\section{References}

1) Sarfert, E. \& H. Venner: Einfaches, schonendes Verfahren zur Deproteinisierung von hochmolekularer Kalbsthymus-Desoxyribonucleinsäure. Naturwissenschaften 49: 423 424, 1962

2) Kanda, N.: A new antibiotic, kidamycin. I. Isolation, purification and properties of kidamycin. J. Antibiotics 24: 599 606, 1971

3) Kanda, N.; M. Kono \& K. Asano: A new antitumor antibiotic, kidamycin. II. Experimental treatment of cancer with kidamycin. J. Antibiotics 25: 553 556, 1972

4) Trouet, A.; D. Deprez-De Campeneere \& C. De Dure: Chemotherapy through lysosomes with a DNAdaunorubicin complex. Nature, New Biol. 239: 110 112, 1972

5) Trouet, A; D. Deprez-De Campeneere, M. De Smedt-Malengreaux \& G. Atassi: Experimental leukemia chemotherapy with a "lysosomotropic" adriamycin-DNA complex. Europ. J. Cancer 10: 405 411,1974

6) Ohnuma, T.; J. F. Holland \& J.-H. Chen: Pharmacological and therapeutic efficacy of daunomycin: DNA complex in mice. Cancer Res. 35: 1767 1772, 1975

7) Rozencweig, M.; Y. Kenis, G. Atassi, M. Staquet \& M. Duarte-Karim: DNA-adriamycin complex: preliminary results in animals and man. Cancer Chemoth. Rep. Part 3, 6: 131 136, 1975

8) Marks, Th. A. \& J. M. Venditti: Potentiation of actinomycin D or adriamycin antitumor activity with DNA. Cancer Res. 36: 496 504, 1976

9) Seeber, S.; R. B. Schilcher, K. P. Brucksch, J. Kädig \& C. G. Schmidt: Cytostatic efficacy of DNAcomplexes of adriamycin, daunomycin, and actinomycin D. II. Comparative in vivo studies in an EHRLICH ascites tumor. Z. Krebsforsch. 90: 307 312, 1977

10) BERG, H. \& K. ECKARDT: Interaction of anthracyclines and anthracyclinones with DNA. Z. Naturforsch. $25 \mathrm{~b}: 362 \sim 367,1970$ 